\title{
人エペプチドによる特異的な無機材料表面認識 \\ Specific Recognition of the Surfaces of Inorganic Materials by Peptide Aptamers
}

\author{
芝 清隆
}

Kiyotaka Shiba

\begin{abstract}
Peptide aptamers are artificially created short peptide sequences that have specific recognition abilities. The technique to create peptide aptamers has been developed in biology field and many peptides that bind to various biomolecules including enzymes, receptors etc. have been isolated since 1990. Recently, this methodology has been applied to create artificial peptides that specifically bind to the surfaces of inorganic materials. Here I introduce our studies on peptide aptamers against titanium and carbon nanohorns, and discuss on the "specificity" that is required for bionanotechnology.
\end{abstract}

Keywords: evolutionary bioengineering, in vitro evolution, bio-nanotechnology, artificial proteins, biomineralization

\section{1. はじめに}

特異的な認識能力をもった生体分子でまず思いつくのが 「抗体分子」であろう。インフルエンザの流行期に，高熱を 出して病院を訪れると, 綿棒で鼻腔内粘膜表皮を採取され, 何やら小さいプレートに塗り付け，待つこと数分，インフ ルエンザかどうかを診断される。この検査プレートに固相 化されているのは抗体分子である。インフルエンザウイル スの核タンパク質に特異的に結合する抗体分子で，通常は A 型と B 型のウイルスを区別できるような 2 種の抗体が用 いられている。われわれもインフルエンザウイルスに感染 すると，体の中ではインフルエンザウイルスに対する特異 的な抗体が作られている。いわゆる免疫反応である。検査 キットを作るには多量の抗体が必要となるので，人為的に 抗体を調製しないといけない。これはマウス体内にウイル ス（あるいはタンパク質）を注入することから免疫を誘導 し，ウイルスに対する抗体を産生する細胞をうまく見つけ 出し，それを細胞レベルで増殖させることから可能となる。

人為的に特定の特異性をもった抗体を作製する, といっ ても, 要はマウスのもつ免疫機構まかせである。免疫機構 は魔法のように, その動物個体が初めて遭遇する外来分子 を特異的に認識する抗体分子を体の中で作り出してくれる。 外来分子は何もタンパク質などの生体高分子に限る必要は ない。化学化合物に対する特異的抗体も広く知られている。 ならば，工学分野で使われるいろいろな無機材料を特異的 に認識する抗体分子は同じように人為的に作りだすことが できるのであろうか？ここでは, 特異的な認識能力をもつ 生体高分子を人為的に作製する技術を，工学分野で利用し ようとする最近のバイオナノテクノロジーの研究を紹介し,
生物学と材料科学の接点における「特異的認識」について 考えてみたい。

\section{2. 人為的な特異的結合分子の作製}

\section{1 「選択」することから創り出す}

免疫システムが未遭遇の外来分子に対して, それを特異 的に認識する抗体分子を生み出す機構は簡単には次のよう なものである。抗体分子はタンパク質なので，基本的には 20 種のアミノ酸がいろいろな順番でつながった直鎖状の分 子である。その並び方でいろいろな特異性を生み出してい ることになる。免疫システムは，外来分子と遭遇して，そ れからそれに合わせて新しいアミノ酸の並びを作り出すの

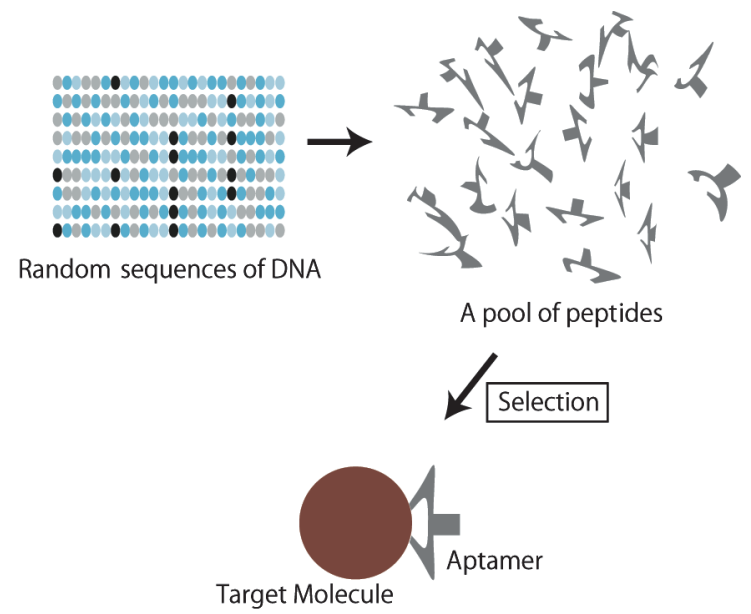

Figure 1. Selection from molecular diversity. In evolutionary molecular engineering experiments, artificial molecules having desired functions are selected from libraries that are prepared from combinatorial polymerization of DNA or amino acid blocks. 
ではなく，実はいろいろなアミノ酸の並びをもった抗体分 子をあらかじめ体の中にたくさん準備している。そして, その中から遭遇した外来分子をうまく認識できる抗体のみ を育てる。あたかも進入した外来分子にあわせて抗体分子 が変化したかのように見えるが, 基本は「多様性集団」か ら適したものが「選択」されるといった進化にも通じる戦 略を利用している。

\section{2 ペプチド提示ファージ・システム}

免疫システムをうまく利用すると, いろいろな材料に対 して特異的に結合する抗体分子がつくれそうである。実際， 例えばフラーレンを特異的に認識する抗体を取得したと主 張する論文なども存在する ${ }^{1}$ 。しかしながら, 現在のところ, この分野でもっぱら使われているのは, 抗体免疫システム ではなく「ペプチド提示ファージ・システム」である。こ れは，抗体システムをもっと単純化したようなもので, ファージと呼ばれる大腸菌に感染するウイルスの表面にい ろいろな配列のペプチドを提示した集団から出発し, その 中から標的分子に結合するファージクローンを選び出す2。 「多様性集団」からの「選択」を基本戦略としていることに は変わりない。Figure 2 にはぺプチドを提示したファージの 模式図を示している。長さが拈よそ $1 \mu \mathrm{m}$ のいくつかの夕 ンパク質とゲノム DNA からなる超分子集合物である。マウ スや動物細胞を必要としないシンプルなシステムであるこ とが, ペプチド提示ファージ・システムが広まった理由の 1 つかもしれない。ちなみに生物学分野では「ペプチド」 「ポリペプチド」「タンパク質」といった言葉が使われるが, いずれもアミノ酸の重合体で，簡単に言ってしまうと短い 重合体がペプチドで, 長いものがポリペプチド, タンパク 質である。

Displayed peptides

Phage body

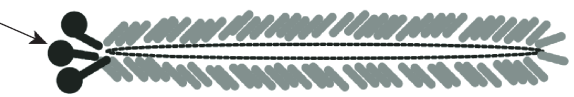

Figure 2. Schematic representation of a peptide-displayed phage. A few copy of peptide (having the same sequence) is displayed on a one end of a filamentous phage body. The phage body is composed of several species of proteins and a phage genome DNA.

\section{3 材料認識ペプチド・アプタマー}

ペプチド提示ファージ・システムなどで取得された特異 的結合能力をもつペプチドは「ペプチド・アプタマー」と 呼ばれている。従来は酵素や受容体などの生体高分子に対 するぺプチド・アプタマーの取得が中心であったが， 2000 年に発表された半導体に対するペプチド・アプタマーの取 得報告 ${ }^{3}$ を境に，その対象範囲が無機材料へと大きく広 がった。最近までに報告されている無機材料に対するぺプ チド・アプタマーは，文献 4 にまとめられている。

われわれの研究室でも,「チタン 5 」カーボンナノホーン

\section{(a) Ti-binding peptide (TBP- 1 )}

\section{Arg-Lys-Leu-Pro-Asp-Ala-Pro-Gly-Met-His-Thr-Trp}

\section{(b) Carbon nanohorns binding peptide (NHBP-1)}

\section{Asp-Tyr-Phe-Ser-Ser-Pro-Tyr-Tyr-Glu-GIn-Leu-Phe}

Figure 3. Sequences of artificial peptides that recognize the surfaces of titanium (a) and carbon nanohorns (b). These peptides were selected using a peptide phage display system.

$\left.(\mathrm{CNH})^{6}\right\rfloor$ に結合するぺプチド・アプタマー（それぞれ， TBP-1，NHBP-1 と命名）を取得している。これら人工ペプ チドの配列を Figure 3 に示してある。これらはいずれも， 12 残基長からなるランダムなペプチド配列の中から選ばれ たものである。

\section{3. ペプチド・アプタマーの工学分野での利用}

\section{1 抗体に比べると随分と小さなぺプチド・アプタマー}

Figure 3 で示すぺプチドは分子量にして 1500 前後である。 これを大きな分子と感じるか, 小さな分子と感じるかは, 研究分野によって異なるであろうが，生体高分子を研究す る者にとっては随分と小さな分子である。タンパク質はた いていが 200 残基以上のアミノ酸が重合したものである。 大きいものでは何千といった残基長をもつ。ちなみに抗体 分子の場合，4つのポリペプチドが集合したもので，全体の 分子量はおよそ十数万といった比較的大きなタンパク質の 部類に属する。すなわち, ペプチド・アプタマーの 100 倍 の大きさをもつ。はたしてこのような小さなぺプチド分子 が, 抗体分子と同じように標的分子を特異的に認識し, 強 く結合できるのか興味深い問題である。以下にわれわれの 研究成果を中心に紹介してみたい。

\section{2 ペプチド・アプタマーの無機材料結合能力}

ファージとは細菌に感染するウイルスのことで，いろい ろな種類があるが，ペプチド提示ファージ・システムでは， Figure 2 で示したような䋊維状ファージと呼ばれる仲間がよ く使われる。Figure 2 に示している分子の大きさの関係は実 際の分子の大きさを反映していない。ファージ本体は長さ が抄よよ $1 \mu \mathrm{m}$ あるのに対して，直径はわずか 6-7 nm で あるので，実際のファージは模式図よりもはるかに大きな アスペクト比をもつ。さらに, 提示されている 12 残基のペ プチドは伸ばした状態でも長さは $2 \mathrm{~nm}$ ぐらいである。この ような小さなぺプチドが，巨大なファージの片端に数コ ピー提示されて抽，ここで，ファージを標的分子につな ぎとめている。イメージとしては 5 メートル長の棒高跳び のポールの先に長さ 1 センチのセロテープが数枚飛び出し ており，このようなポールが海中において，テープ部分で 
岩に結合し，大きな波がきてもびくともしない，といった 感じである。感覚的にはペプチド・アプタマーは随分と強 い結合力をもつようであるが, 定量的にはどうなのであろ うか?

生体高分子の結合は基本的には水素結合, 電気的相互作 用，ファン・デル・ワールスカ，疎水結合が合わさった 「非共有結合」である。また, 生体高分子の結合は水の存在 を前提とする。したがって, 生体高分子間の結合の強さの 指標として, 解離平衡定数がしばしば用いられる。抗体と 抗原との解離平衡定数は，普通 $\mathrm{nM}$ のオーダーで，中には $\mathrm{pM}$ のオーダーの強い結合を示す抗体抗原の組み合わせも存 在する。一般的に生体高分子はその目的に応じて， $\mu \mathrm{M} \sim$ $\mathrm{pM}$ の範囲の解離平衡定数でそれぞれ分子間相互作用してい るが，その中でも抗体抗原の結合は最も強い部類の 1 つで ある。

ペプチド提示ファージは（結合するものとして選択して きたわけだから）標的材料に結合することは明らかなので, この複合体の示寸解離平衡定数を求めたいところであるが, 前述したようにファージ本体が高いアスペクト比をもつ等 の理由も含め, なかなか適当な評価系が存在しない。そこ で，提示したペプチド配列，TBP-1 と同じ配列をもつペプ チドを化学合成し，この合成ペプチドを用いてチタン粒子 に対する解離平衡定数を求めてみた 7 。得られた值は, 10 $\mu \mathrm{M}$ のオーダーのものであり, 非常に弱い結合能であった。

実は，ペプチド提示ファージで取得されたペプチドが， ファージ本体から切り離された場合に, 結合能力が極端に 悪くなる（あるいは失う）のはしばしば耳にする話である (このような場合そもそも論文にはならない)。その理由は いくつか考えられる。ファージ提示状態では, 上述のよう に数コピーのペプチドが 1 つのファージに結合しているわ けなので，多価提示状態となっている。単離されたペプチ ドより強い結合能力をもつことが容易に想像できる。他に も，ファージ本体の提示されたペプチド近傍のタンパク質 のある領域が，何らかの形で結合に寄与している可能性が 考えられる。もっとも嫌な可能性は, 得られたペプチドが ファージに提示された状態でしか, 特異的な結合能力を示 さない場合である。しかしながら，このような可能性は， 得られたペプチドを他の分子に移植し，移植された分子が ペプチドの持つ特異的な結合能力を獲得することを確認す ることで排除できる。

われわれは，後述する理由を含めて，ペプチド・アプタ マーを移植する分子としてフェリチンを選んだ。フェリチ ンは直径が $12 \mathrm{~nm}$ のナノ球状タンパク質である。ヒトから, 植物，細菌にいたるまでフェリチン（および同等タンパク 質）は広く分布し，ヒトでは，血中での鉄貯蔵タンパク質 として機能していると考えられている。 L 鎖, $\mathrm{H}$ 鎖の 2 種 のポリペプチドから構成されるへテロ 24 量体だが, どちら か片方のポリペプチドを用いた大腸菌組換え系でも，天然

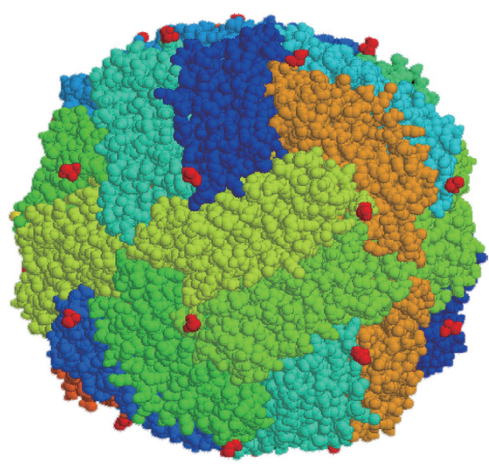

Figure 4. Schematic drawing of ferritin molecule. Ferritin is composed of 24 subunits (L-chain and H-chain). The N-terminal of the units are shown by red dots.

フェリチンと同じようなナノ粒子を形成させることができ る。

フェリチンの立体構造を眺めると，うまい具合にその N 末部分がナノ粒子の表面に露出している。そこで, 組換え フェリチンのサブユニット遺伝子の $\mathrm{N}$ 末端部分に相当する 部分に，TBP-1 をコードする DNA 配列を挿入し， N 末部分， すなわちフェリチンの粒子表面に TBP-1 を提示するような 改変フェリチン分子を作製してみた。また，この時点で， 12 残基の TBP-1 のうち, チタンへの結合に必須な配列は, 前半の 6 残基（これを $\operatorname{minTBP}-1$ と命名）であることがわ かっていたので 5 , 実際にはフェリチンサブユニットに挿入 したのは，6 残基配列，RKLPDA であった。

得られた改変フェリチン $(\operatorname{minT} 1-\mathrm{LF})$ は予想どおり, TBP-1 が持つチタンへの特異的結合能力を示した 9 。そこで, このチタン結合能力を賦与された改変フェリチンのチタン 表面への解離平衡定数を求めた。今度は, $3.8 \mathrm{nM}$ といった, 抗体・抗原の結合に匹敵する強い結合能力が観察された9。 わずか 6 残基のペプチドを移植するだけで，フェリチン粒 子にチタン表面への十分に強い結合能力を賦与することが できたわけだ。われわれは同様に，NHBP-1 を提示する改変 フェリチンも作製し，こちらからもカーボンナノホーン表 面に結合能力をもつ改変フェリチンの作製に成功している9。

\section{3 特異的な結合とは何を意味するか?}

ここまでは深く説明することなく「特異的な結合」とい う言葉を使っていた。ここでは，「特異的な結合」の意味を 少し考えてみたい。

2000 年に半導体に結合するぺプチドがペプチド提示 ファージ・システムで単離・報告 ${ }^{3}$ された時，それまで生 体高分子を標的として同種の実験を進めていた生物学者が まず思ったのが，「これって本当に特異的結合ペプチドな の?!」であった。ペプチド提示ファージ実験を進める上で の注意点の 1 つが, 選択過程で, ピペットチップや反応 チューブなどの材料表面に結合するファージを目的の ファージとして勘違いするな,である。つまり，得られた ファージが，本当に狙った通りに標的分子に結合している 
のか，あるいは，実験に用いるいろいろな機器の表面に結 合しているものを特異的結合ペプチドとしていないか, 十 分なコントロール実験をおくように注意しなければならな い。実際，反応チューブに結合しやすいペプチド配列等が 論文として発表されており，実験者に注意を促している9。 これら無機材料結合ペプチドは「非特異的結合ペプチド」 として避けられていたのである。しかし，半導体結合ペプ チドは，この非特異的結合ペプチドを積極的に選択したよ うなものである。ターゲットが生体高分子であるから特異 的結合ペプチドであり，ターゲットが無機材料たから非特 異的結合ペプチド，とはならないのである。どちらも，積 極的に結合物を選択しているわけだから，等しく特異的結 合ペプチドを創製する実験なのである。

しかしながら, 生物分野の研究者が半導体結合ペプチド の報告論文の結果にすっきりしたものを感じなかった理由 のもう 1 つが, 得られた配列群に関係している。ペプチ ド・提示ファージ実験の基本的な流れは Figure 1 にあるよ うに多様性集団の中から結合能力をもつクローンを選択す るわけだが, 通常, 最終的に選択されるクローンは複数種 となる。そして, しばしば, その複数種の配列を比較する と，共通した配列構造を見いだすことができる（例えば， 4 つの異なる 12 残基の配列があるが，いずれの配列も共通 して RGDK といった 4 つの連続した配列をどこかに持つ， 等)。このような配列の共通性が見いだされた時, 実験者は 実験がうまくいったなと，ひとまず胸をなでおろすのであ る。ところが, 報告された 11 種の GaAs（100）結合ペプチ ドの間には共通配列は存在していなかった 3 。電子供与性の あるアミノ酸残基が多いことが指摘されているが, 当時の 生物分野の研究者の感覚からすると, 発表をためらう結果 である。単に, 非特異的結合ペプチドの中の, ある傾向の ものだけを選んでいるのではないかという穿った見方もで きる。いや，その「ある傾向のものを選ぶ」といったこと こそが, 特異的結合ペプチドを選択したことになるのだ, ともいえる。

こう考えていくと, そもそも生体高分子の間においても 「特異的結合」とは何なのか？ということになってくる。冒 頭に述べたように，インフルエンザウイルスを特異的に認 識する抗体を取得する場合, マウスにインフルエンザウイ ルスを接種し, 免疫反応を誘導することでおこなう。この 場合, マウスの免疫システムは, マウス自身がもついろい ろなタンパク質を自己として，接種したインフルエンザウ イルスを非自己として特異的に識別する。免疫といった 1 つのシステムの中で特異性が定義できる。では, A 型と B 型を区別する抗体の場合はどうであろう？マウスにとって は, $\mathrm{A}$ 型も $\mathrm{B}$ 型もどちらも等しく非自己であり, 特異的に 識別する必要は無い。事実, A 型と B 型の両方を同じよう に認識する抗体もマウスの中では作られているはずだ。い ろいろ作られた抗体の中で，われわれが検査キットとして
使い勝手がよいものを「特異性が高い良い抗体」と称して 使っている。マウスの免疫システムにとっては, この識別 は必ずしも必要ないものなのかもしれない。

実は, ペプチド提示ファージ・システムで保証されてい るのは, ペプチド提示ファージ・システム内での特性であ る。すなわち，選択実験の過程でペプチドが出会うもろも ろの有機材料，無機材料と標的分子間の識別である。すな わち，得られてきたぺプチドは，確かに標的分子を，プラ スチックチューブや，ブロッキング剤として用いる特定夕 ンパク質から区別できるが，システムに含まれていない未 知の標的分子に対して，どのような振る舞いをするのかは， あらかじめ分からないのである。

\subsection{TBP-1 の特異性は?}

前節では特異性についてあれこれと論じてみたが，要は， 創製したペプチドを最終的に用いるシステム内で必要十分 な特異性があるかどうか? である。無機材料結合ペプチド の多くは, ナノバイオテクノロジーの分野での利用が想定 されている。想定されているシステムの中で, 必要な特性 が出せればそれで OK なのだ。

われわれはチタンに結合する TBP-1 を単離した5。TBP1 の最終的な応用利用目標は，1つにはバイオマテリアルと してのチタン表面の機能化に利用するためである。例えば, 骨化誘導能力をもったサイトカインなどを, TBP-1 を介し てチタンインプラントの表面などに固相化し，生体内での チタンインプラントの骨接合を改善しようとするものだ。 この場合, ヒトの生体システムの中で, 十分に期待した TBP-1 の特異性が発揮できるかどうかが問題となる。in vivo 実験が中心となるので, 結論が出るまでには, まだ少し時 間を必要とする。

TBP-1 のもj 1 つの出口が, バイオナノテクノロジー分 野での利用である。すなわち, ボトムアップなナノデバイ ス構築に，TBP-1のもつ特異的認識能を利用することであ る。この場合，デバイス作製過程で用いられる各種無機材 料の間を識別する能力があるかどうかが鍵となる。そこで, われわれは，チタンを含む 10 種の無機材料（主に金属）に 関して，TBP-1の結合能力を評価してみた。その結果, TBP-1 は, チタン, 銀, シリコンの表面には結合するが, 金, プラチナ, 銅, 鉄, クロム, 亜鉛, スズには結合しな かった 7 。デバイス作製を考えると十分に使える特異性であ る。デバイス作製で頻用されるシリコン表面に結合するの が少々問題とも思えたが，その後，結合時の条件を工夫す ることなどにより，チタンと酸化シリコン基板との識別も 可能であることも分かっている10。Figure 5 には，TBP-1の もつ特異的結合能力を用いたナノデバイス作製につながる 応用実験の 1 つを示している。ここでは，前述の minTBP-1 提示フェリチン (minT1-LF) が用いられている。酸化チ夕 ン基板上にチタン薄膜をナノパターン化したものを作製し, 


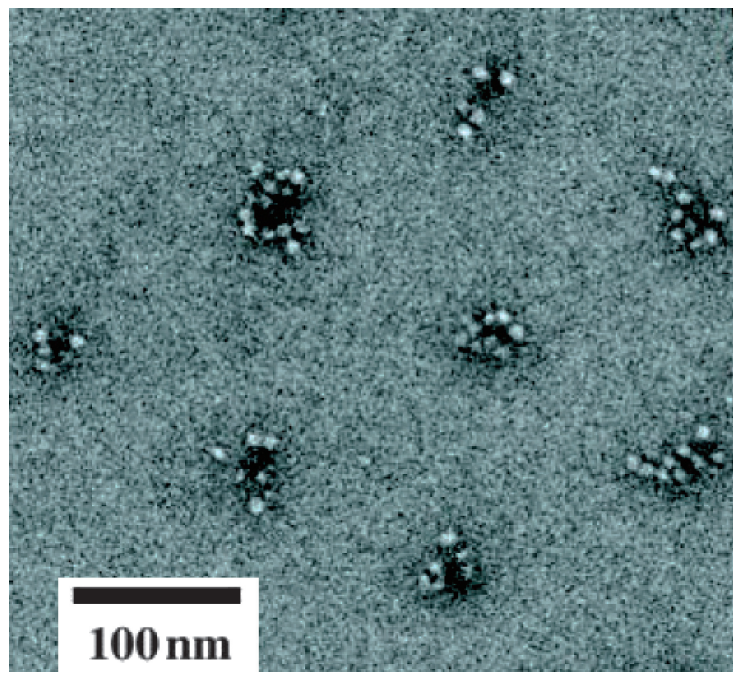

Figure 5. Specific positioning of minTBP-1 displayed ferritin on titanium regions patterned on $\mathrm{SiO}_{2}$ substrate.

このパターン基板に minT1-LF 溶液を流し, 軽く洗浄するだ けで，図のように特異的なフェリチン配置を実現している $10 。$

\section{$3.5 \mathrm{NHBP}-1$ の特異性は?}

TBP-1 に比べるとカーボンナノホーンに結合する NHBP1 の特異性に関しては, 研究があまり進んでいない。その理 由は炭素化合物, 金属類と異なり, 薄膜作製などが容易で ないことにある。

NHBP-1 は, カーボンナノ化合物の中でも，特に「カー

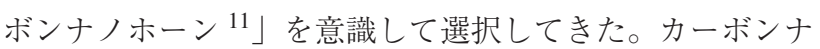
ノホーンは, 広くはカーボンナノチューブの仲間であるが, その合成には触媒金属を使用しないことが，カーボンナノ 材料の医療方面での応用 12 で大きな利点となる。NHBP-1 の想定利用システムも生体であるために，十分な特異性が あるかどうかは in vivo の評価実験をまたなければならない。 現在，少なくとも in vitro では，カーボンナノホーン表面の 改質に利用できるだけの十分な特異性と結合能力を発揮で きることが分かっている。

\section{6 ペプチド・アプタマーの多機能性}

ペプチド・アプタマーは，「結合活性」を指標に選択され ている。ところが，面白いことに，調べてみると結合活性 以外にいろいろと面白い活性をあわせ持つことが分かって きた。

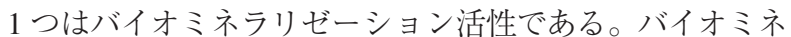
ラリゼーションとは, われわれの骨や歯, あるいは貝殼な どがそうであるように，生物が無機物の結晶（多くはアモ ルファスなのだが）を水中の温和な条件で形成する現象で ある ${ }^{4}$ 。バイオナノテクノロジーでも是非利用したい生体高 分子の特性の 1 つなのであるが, 天然のバイオミネラリ ゼーションが対象とするのが, リン酸カルシウムやシリカ に限られているという問題もあった。なんとかバイオミネ
ラリゼーションの適応範囲を広げられないかと試行錯誤が 続く中で，無機材料結合ペプチドがもつミネラリゼーショ ン能力に注目が集まっている。

そもそも，無機物表面への生体高分子の結合と，バイオ ミネラリゼーションが表裏一体の現象ではないかという考 えは，バイオミネラリゼーション研究初期の段階から提案 されていた ${ }^{14}$ 。したがって, ペプチド・アプタマーの研究 者にも，ペプチド・アプタマーが水中での無機物結晶化に 何らかの影響を与えるのではないかという期待が早い段階 であったと言えよう。前述の半導体結合ぺプチドを取得し たグループも，アプタマーのもつミネラリゼーション活性 の研究を精力的に進めている ${ }^{15}$ 。

われわれも TBP-1 が結合標的である, チタン, 銀, シリ コンのミネラリゼーションに影響をもつかを調べた。その 結果, TBP-1 は, シリカ, 銀, チタニアのミネラリゼー ションを促進する活性をもつことが分かった7,16。さらに， この TBP-1のもつ「結合活性」と「ミネラリゼーション活 性」を交互に利用してナノ多層薄膜を形成する, BioLBL 法 を考案している ${ }^{17}$ 。BioLBL 法は, 間質層にシリカやチタニ アの薄層を用いるために，層間拡散が抑えられるといった， 従来の Layer-by-Layer 法に無い長所をもっている。トップ ダウンのリソグラフィー法と組み合わせることにより，水 中での 3 次元ナノ構造体の形成に成功している ${ }^{16}$ 。

NHBP-1 に関しても結合活性以外の興味深い機能が明ら かになってきている。NHBP-1 の配列はかなり疎水的な残 基を多く含むが，これと関連してか，NHBP-1 は高い自己 集合能力をもつ。合成ペプチドそのものが塩の存在下で繊 維状のマクロ構造を形成するのに加えて, NHBP-1 を他の可 溶性のタンパク質に賦与することで，そのタンパク質に自 己集合能力を賦与することができる18。また，前述の $\operatorname{minTBP}-1$ 提示フェリチンと同じように, NHBP-1 提示フェ リチン分子を作製すると，フェリチンが二次元の最密結晶 アレイを形成することが明らかになっている。ペプチド . アプタマーのあわせ持つ, このような自己集合能力も，工 学的に利用価値のある機能のようである。

\section{4. ペプチド・アプタマーの基礎科学としての面白さ}

前章ではペプチド・アプタマーの応用側面に焦点を当て て紹介したが，基礎科学としてのペプチド・アプタマー研 究も最後に紹介しておきたい。

まず，何といってもどのような分子機構でペプチドが無 機材料の表面を認識しているかが一番の興味であろう。生 体高分子に結合するぺプチド・アプタマーならば両者の共 結晶構造解析を進めればかなりのことがわかるのであるが, 標的が無機材料の場合には結晶化は望めない。ペプチド単 体の NMR 構造解析も 1 つの可能性で, NHBP-1 に関しては, NMR のデータが得られたものの ${ }^{20}$, これだけでは結合の機 構解明にはいたらない。ペプチド・アプタマーの結合機構 


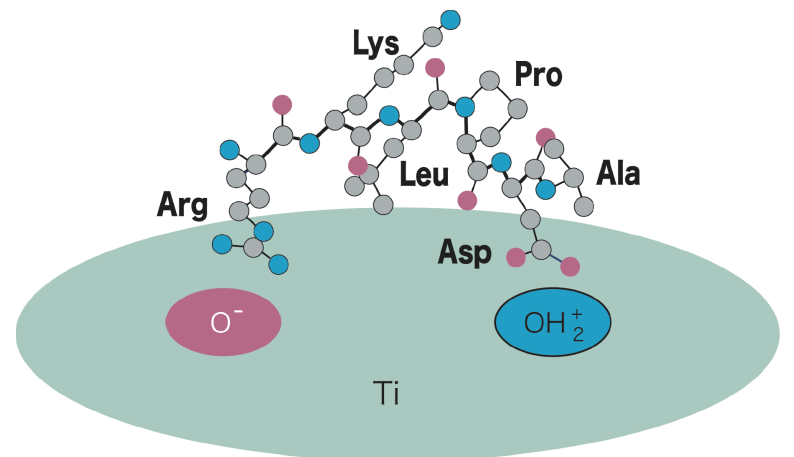

Figure 6. A model for the recognition of the surface of Ti by minTBP-1 peptide.

の解明には, ペプチドの変異体（各位置のアミノ酸が他の アミノ酸に変化したもの）をうまく利用し, 複数の解析法 を組み合わせて迫っていくのが現実的な方法なのであろう。 われわれは既に, TBP-1の各位置をアラニンに変化させた 変異体を作製し, そのチタンへの結合能力の変化の観察か ら, TBP-1 はチタン表面の水酸化膜の電荷パターンを認識 して結合しているというモデルを提案している (Figure 6) 5 。 さらに, $\operatorname{minTBP}-1$ を提示するフェリチン分子, $\operatorname{minT1-LF}$ を利用した $\mathrm{AFM}$ 解析から, このモデルの裏付けとなるデー 夕を得ている21。現在, 変異体 minTBP-1 を提示するフェリ チン分子と $\mathrm{AFM}$ を用いて, さらに深い知見を得る作業を進 めている。

TBP-1 はチタンの他にも, 銀やシリコンの表面に結合す る。これまでの材料科学の常識では, チタン, 銀, シリコ ンの表面は特に共通の性質は指摘されていない。無機材料 結合ペプチドは, このように, 表面科学の分野に新しい切 り口を与える道具となる可能性も潜めている。

さらに, ペプチド・アプタマーが与える, バイオミネラ リゼーションへのインパクトも指摘しておきたい。バイオ ミネラリゼーション研究は長い歴史をもつものの, 未だに その分子機構がはっきりとしない難しい研究テーマである。 ようやく最近バイオミネラリゼーションに関わるタンパク 質自体の配列構造, 高次構造が明らかにされているような 状況である。タンパク質の場合, 変異体を作製するにして も, 構成するアミノ酸の数が多いために, 何らかの工夫が 必要である。バイオミネラリゼーション関連タンパク質が 共通に持つ，短いペプチド配列（モチーフと呼ぶ）に焦点 をあてて実験を進めるのも1つの手法であるが, 最初から 短いペプチドとしてバイオミネラリゼーション活性をもつ ペプチド・アプタマーは, 比類ない研究材料となる。今後, ペプチド・アプタマーを利用したバイオミネラリゼーショ ン研究が飛躍的に進展するものと期待している。

\section{5. おわりに}

無機物に結合するペプチド・アプタマーはバイオナノテ クノロジーの強力なツールとなると期待され, 2000 年以降
大きな進展を遂げた。現在, 主だった無機材料に対するぺ プチド・アプタマーの単離は完了しているといった状況で ある。次なるこの分野の挑戦は, これらぺプチド・アプタ マーを用いて, どのように自己組織化的に複雑なナノ構造 を形成するシステムを作製するかである。天然の生体高分 子が自己組織化的に複雑なナノ構造を形成するからといっ ても，結合活性で選択した人工進化ぺプチドが，そのまま 自己組織化的に何らかの構造を形成してくれるというわけ にはいかない。実は, そもそも天然タンパク質の自己組織 化機構についても, われわれはほとんど何もわかっていな いのかもしれない。この方面の研究に関しても, ペプチ ド・アプタマーが新しい展開を導いてくれるかもしれない。 いずれにせよ, 応用利用に先走ることなく, 地道に結合分 子機構やミネラリゼーション機構を解析していくことが, バイオナノテクノロジーが次のステップヘと飛躍する近道 であろう。

\section{6. 謝辞}

ここで紹介した研究のうち, チタン結合ペプチドに関す る研究は佐野健一研究員, カーボンナノホーン結合ペプチ ドに関しては加瀬大介君，松村幸子研究員を中心に進めら れたものである。また，フェリチンを利用したデバイス開 発では, 奈良先端科学技術大学院大学の山下一郎博士, カーボンナノホーンでは, 名城大学の飯島澄男博士, 日本 電気（株）の湯田坂雅子博士に多大なご協力をいただいて いる。ここで改めてこれらの人々に感謝したい。

\section{引用文献}

(1) Chen, B. X.; Wilson, S. R.; Das, M.; Coughlin, D. J.; Erlanger, B. F. Proc. Natl. Acad. Sci. USA 1998, 95, 10809-10813.

(2) Scott, J. K.; Smith, G. P. Science 1990, 249, 386-390.

(3) Whaley, S. R.; English, D. S.; Hu, E. L.; Barbara, P. F.; Belcher, A. M. Nature 2000, 405, 665-668.

（4）芝 清隆, 佐野健一, バイオミネラリゼーションとそれに 倣う新機能材料の創製; 加藤隆史 編; シーエムシー出版 : 東京, 2007; pp 273-287.

(5) Sano, K.; Shiba, K. J. Am. Chem. Soc. 2003, 125, 14234-14235.

(6) Kase, D.; Kulp, J. L.; Yudasaka, M.; Evans, J. S.; Iijima, S.; Shiba, K. Langmuir 2004, 20, 8939-8941.

(7) Sano, K.; Sasaki, H.; Shiba, K. Langmuir 2005, 21, 3090-3095.

(8) Sano, K.; Ajima, K.; Iwahori, K.; Yudasaka, M.; Iijima, S.; Yamashita, I.; Shiba, K. Small 2005, 1, 826-832.

(9) Menendez, A.; Scott, J. K. Anal. Biochem. 2005, 336, 145-157.

(10) Yamashita, I.; Kirimura, H.; Okuda, M.; Nishio, K.; Sano, K.; Shiba, K.; Hayashi, T.; Hara, M.; Mishima, Y. Small 2006, 2, 1148-1152.

(11) Iijima, S.; Yudasaka, M.; Yamada, R.; Bandow, S.; Suenaga, K.; Kokai, F.; Takahashi, K. Chem. Phys. Lett. 1999, 309, $165-170$

(12) Shiba, K. In Nanomaterials for Cancer Diagnosis; Kumar, C. S. S. R., Ed.; Wiley-VCH: Weinheim, 2007; pp 285-303. 
(13) Matsumura, S.; Ajima, K.; Yudasaka, M.; Iijima, S.; Shiba, K. Mol. Pharm. 2007, 4, 723-729.

(14) Weiner, S.; Hood, L. Science 1975, 190, 987-989.

(15) Lee, S. W.; Mao, C.; Flynn, C. E.; Belcher, A. M. Science 2002, 296, 892-895.

(16) Sano, K.; Yoshii, S.; Yamashita, I.; Shiba, K. Nano Lett. 2007, 7, 3200-3202.

(17) Sano, K.; Sasaki, H.; Shiba, K. J. Am. Chem. Soc. 2006, 128, 1717-1722.

(18) Sano, K.; Sasaki, H.; Shiba, K. Protein Eng. Des. Sel. 2007, 20, 109-116.
(19) Matsui, T.; Matsukawa, N.; Iwahori, K.; Sano, K.; Shiba, K.; Yamashita, I. Langmuir 2007, 23, 1615-1618.

(20) Kulp III, J. L.; Shiba, K.; Evans, J. S. Langmuir 2005, 21, 11907-11914.

(21) Hayashi, T.; Sano, K.; Shiba, K.; Kumashiro, Y.; Iwahori, K.; Yamashita, I.; Hara, M. Nano Lett. 2006, 6, 515-519.

(22) Shiba, K.; Minamisawa, T. Biomacromolecules 2007, 8, 2659-2664.

（受理日 2007 年 10 月 16 日）

\footnotetext{
芝 清隆（しば きよたか）

所属 : 財団法人癌研究会 癌研究所 蛋白創製研究部

専門分野: 分子生物学

連絡先：干 135-8550 東京都江東区有明 3-10-6

電子メール：kshiba@jfcr.or.jp

URL : http://cell.jfcr.or.jp
} 